\title{
Production Factor Efficiency of Shallot Farming in Pati, Central Java, Indonesia
}

\author{
Triyono ${ }^{1, *}$, Muhammad Fauzan ${ }^{1}$, Jamilatul Mu'awanah ${ }^{1}$, and Muliati Sedek ${ }^{2}$ \\ ${ }^{1}$ Agribusiness Department, Universitas Muhammadiyah Yogyakarta, Jl. Brawijaya, Kasihan Bantul \\ Yogyakarta, Indonesia \\ ${ }^{2}$ Universiti Teknikal Malaysia Melaka, Malaysia
}

\begin{abstract}
This study aims to analyze factors influencing shallot production and the allocative efficiency of shallot farming in Pati Regency Central Java. Based on data from the association of farmer groups (Gapoktan), there were 12 farmer groups. Using multistage random sampling, four farmer groups and 73 farmers were taken as samples. Data were obtained using interviews and questionnaires. Then, the data were analyzed using the Cobb-Douglass production function and efficiency analysis. The results revealed that factors of land area, seeds, $\mathrm{KNO}_{3}$ fertilizer, and family labor significantly possitive affected shallot production. In general, all of the production factors have not been allocatively efficient. To enhance efficiency, farmers should increase the use of production inputs such as land, seeds, fertilizers, and labor.
\end{abstract}

\section{Introduction}

Central Java Province is the highest shallot-producing province in Indonesia, with Brebes Regency as the main production center. In addition to Brebes and Demak Regencies, Pati Regency is a new shallot production center in Central Java for the last five years with high land productivity, enabling it to produce abundant and sustainable shallot production in supporting shallot production in the province [1].

Table 1. Harvest Area and Production of Shallots in Central Java in 2016-2018

\begin{tabular}{|c|c|c|c|c|c|c|}
\hline \multirow[b]{2}{*}{$\underset{\text { City }}{\text { Regency/ }}$} & \multicolumn{2}{|c|}{2016} & \multicolumn{2}{|c|}{2017} & \multicolumn{2}{|c|}{2018} \\
\hline & $\begin{array}{c}\text { Harvest } \\
\text { Area } \\
\text { (Ha) }\end{array}$ & $\begin{array}{l}\text { Production } \\
\text { (ku) }\end{array}$ & $\begin{array}{c}\text { Harvest } \\
\text { Area } \\
\text { (Ha) }\end{array}$ & $\begin{array}{l}\text { Production } \\
\text { (ku) }\end{array}$ & $\begin{array}{c}\text { Harvest } \\
\text { Area } \\
\text { (Ha) }\end{array}$ & $\begin{array}{l}\text { Production } \\
\text { (ku) }\end{array}$ \\
\hline Boyolali & 1,796 & 216,869 & 1,031 & 107,950 & 1,173 & 75,061 \\
\hline Grobogan & 904 & 79,818 & 1,293 & 120,453 & 1,235 & 123,283 \\
\hline Pati & 3,092 & 350,692 & 3,615 & 394,725 & 2,541 & 270,722 \\
\hline Demak & 6,218 & 599,053 & 6,326 & 533,539 & 5,232 & 432,766 \\
\hline Temanggung & 1,675 & 136,983 & 1,440 & 110,282 & 1,309 & 104,368 \\
\hline Kendal & 3,331 & 320,936 & 3,444 & 318,863 & 1,981 & 184,334 \\
\hline Tegal & 1,834 & 193,653 & 2,306 & 225,026 & 1,901 & 161,271 \\
\hline Brebes & 32,434 & $3,386,832$ & 29,017 & $2,725,988$ & 28,689 & $2,905,637$ \\
\hline Total & 51,284 & $5,284,836$ & 48,472 & $4,536,826$ & 44,061 & $4,257,442$ \\
\hline
\end{tabular}

Source: [1]

* Corresponding author: triyono@umy.ac.id 
The production and productivity of shallots in Pati Regency depicted a fluctuating trend during 2012-2018. Hence, it requires serious attention, considering that shallot farming is a fairly risky business. In addition to the need for relatively expensive production inputs, the price of production (output) was also unstable [2]. The decline in shallot production and the fluctuating purchase price of shallots from farmers during the harvest season means that the income earned cannot cover the production costs incurred during farming, even though the local government has subsidized seeds. Therefore, farmers must be careful in allocating production factors such as seeds, organic and chemical fertilizers in controlling plantdisturbing organisms, labor, and doses of pesticides used in shallot farming. Hence, this paper discusses factors affecting shallot production and the efficiency of production factors in shallot farming.

Table 2. Shallot Production in Pati Regency 2012-2018

\begin{tabular}{|c|c|c|r|}
\hline Year & $\begin{array}{c}\text { Harvest Area } \\
\text { (ha) }\end{array}$ & $\begin{array}{c}\text { Production } \\
\text { (ku) }\end{array}$ & $\begin{array}{c}\text { Produktivity } \\
\text { (ku/ha) }\end{array}$ \\
\hline 2012 & 2,095 & 163,222 & 77.9 \\
\hline 2013 & 2,061 & 216,540 & 105.1 \\
\hline 2014 & 2,402 & 232,290 & 96.7 \\
\hline 2015 & 1,518 & 137,651 & 90.7 \\
\hline 2016 & 3,092 & 350,692 & 113.4 \\
\hline 2017 & 3,615 & 394,725 & 109.2 \\
\hline 2018 & 2,541 & 270,722 & 106.5 \\
\hline mean & $\mathbf{2 , 5 9 0 , 5 7}$ & $\mathbf{2 5 2 , 2 6 3 . 1 4}$ & \\
\hline
\end{tabular}

Source: [2]

Production and efficiency are benchmarks for the performance of a farm. Production is influenced by input production factors, environment, and technology. Meanwhile, efficiency is affected by farmer management and the use of technology in farming. Managerial is associated with socio-economic conditions of farmers, such as age, education, experience, and availability of capital. Technology is closely related to farmer management, especially in terms of the ability to adopt innovation and technology in farming.

Several previous studies have revealed the influence of production, managerial and technological factors on agricultural production. The wide variables, the number of seeds, compound fertilizer, urea fertilizer, pesticides, machine work, manual work affected the production and income of wheat farming [3]. It also applies to wheat production in Pakistan, showing that the level of agricultural technical efficiency was relatively low, mainly due to the relatively long production method and inefficient use of agricultural inputs [4]. Other findings disclosed that credit, farm size, fertilizer, and labor significantly affected rice productivity in Sindh, Pakistan [5]. Meanwhile, household size, agricultural land area, water sources, market accessibility, health symptoms, income, and labor were closely related to technical efficiency and the amount of organic rice production [6]. Moreover, labor was the most crucial factor to explain the loss of agricultural efficiency in Korea [7]. Furthermore, regarding natural resources and the environment, the planted area significantly affected yields in the dry season, but in the rainy season, planted area, labor, $\mathrm{N}$ fertilizer, and seeds were factors that significantly affected yields [8].

Several factors generally affected production efficiency in both Thailand and Cambodia. These factors were farm size, per capita income, number of agricultural credits, level of commercialization, and share of non-agricultural income [9]. Maize farming in eastern Ethiopia uncovered that farmers who participated in off-farm activities significantly increased technical efficiency compared to non-participating farmers [10]. 
Shallots are slow-growing and shallow-rooted plants with no shaded habitus; thus, their productivity is highly dependent on the availability of water in the soil, proper fertilization, and weed control [11]. Meanwhile, organic mulch has been effective for weed control and can be a potential alternative to synthetic herbicides, hoeing or removing weeds by hand in organic shallot farming [12]. Moreover, the addition of organic fertilizer to the soil has positively affected the fresh weight of plants [13], indicating the effect of organic fertilizer on shallot production. Economically, organic shallot production could increase income by $9 \%$ and employment by $18 \%$ [14].

The use of natural ingredients such as plant extracts could be a safe alternative to chemical fertilizers and plant regulators for shallot plants [15]. The application of bioagents protects shallots from Botrytis disease and increases the antioxidant compounds. Hence, it has encouraged the application of these preparations to manage shallot production, especially in organic agriculture, which prohibits any chemicals [16].

The aspect of using technology in shallot farming was investigated by [17], discovering that cut irrigation techniques were considered an efficient and effective intervention approach for increasing shallot yields while maintaining post-harvest quality and saving water. Meanwhile, automation was the main factor in developing automatic shallot planting machines to save farmers' time and labor costs to plant shallots in a row [18].

The relationship between production and production factors has provided an overview of the influence of production factors on shallot production. In this regard, [19] disclosed that factors significantly influencing shallot production were land, seeds, Za fertilizer, SP36 fertilizer, NPK fertilizer, and pesticides. Meanwhile, [20] discovered that inputs such as human labor, nurseries, manure, urea, TSP, irrigation, and insecticides positively affected shallot yields. A study of [21] has provided information that land, labor, and capital costs were estimated to have a significant positive effect on shallot production. Similarly, another study revealed that land, labor, and seeds affected shallot production in various scales from small, medium, and large[22].

Several previous studies have provided an overview of the effect of various production factors on shallot yields. However, there is still a limited analysis of the production function concerning the allocative efficiency of shallot farming. As a result, this article looked at the elements that influence shallot production and how to maximize the efficiency of using these factors in shallot farming.

\section{Research Method}

The location of the study was determined intentionally. In this study, Wedarijaksa District was selected for being one of the largest shallot-producing areas in Pati Regency. Employing multistage random sampling, four farmer groups of Gemah Ripah, Sedoro Sentosa, Tani Rahayu, and Tani Makmur, and 73 farmers were obtained as samples.

Analysis of shallot farming data in 2019 utilized the Cobb-Douglas production function. It is a function or equation that involves two or more variables, where one variable is called the dependent variable or explained variable $(\mathrm{Y})$, and the other is called the independent variable or variable that explains the variable (X) [23] [24]. The estimation of the CobbDouglas production function could provide elasticity values for each of the production input variables. Mathematically, the Cobb-Douglas function is a power function that can be written as follows.

$Y=\beta_{0} X_{1}{ }^{\beta 1} X_{2}{ }^{\beta 2} X_{3}{ }^{\beta 3} X_{4}{ }^{\beta 4} X_{5}{ }^{\beta 5} X_{6}{ }^{\beta 6} X_{7}{ }^{\beta 7} X_{8}{ }^{\beta 8} X_{9}{ }^{\beta 9} X_{10}{ }^{\beta 10} X_{11}{ }^{\beta 11} X_{12}{ }^{\beta 12} X_{13}{ }^{\beta 13} X_{14}{ }^{\beta 14} e^{u}$

Information:

Y : production $(\mathrm{kg})$ 


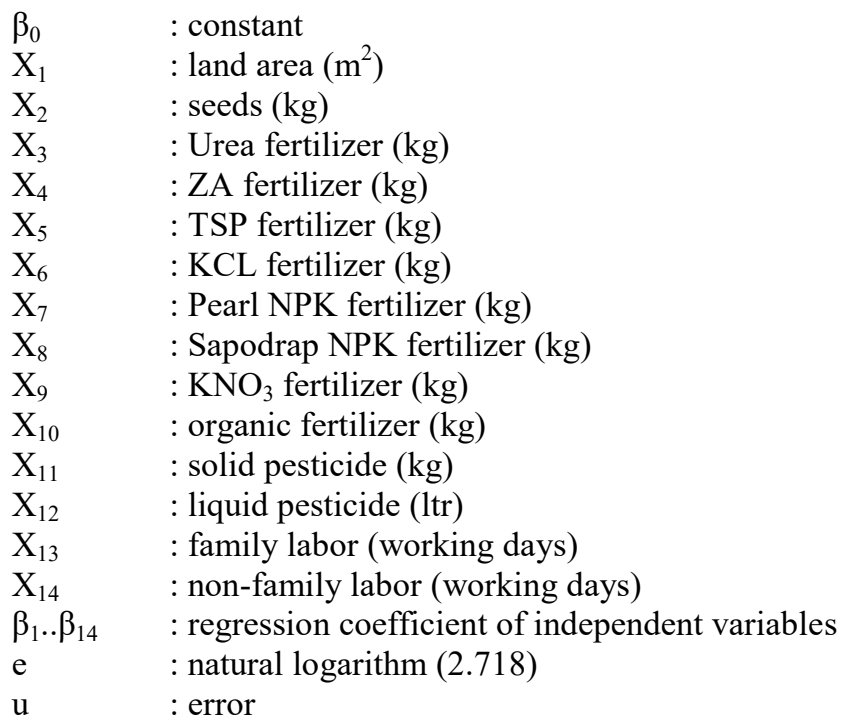

The estimation of the Cobb Douglas production function was performed by transforming the equation function into multiple linear forms (natural logarithm).

$$
\begin{aligned}
\operatorname{LnY}= & \operatorname{Ln}_{0}+\beta_{1} \operatorname{LnX}_{1}+\beta_{2} \operatorname{LnX}_{2}+\beta_{3} \operatorname{LnX}_{3}+\beta_{4} \operatorname{LnX}_{4}+\beta_{5} \operatorname{LnX}_{5}+\beta_{6} \operatorname{LnX}_{6}+\beta_{7} \operatorname{LnX}_{7}+\beta_{8} \operatorname{LnX}_{8} \\
& +\beta_{9} \operatorname{LnX}_{9}+\beta_{10} \operatorname{LnX}_{10}+\beta_{11} \operatorname{LnX}_{11}+\beta_{12} \operatorname{LnX}_{12}+\beta_{13} \operatorname{LnX}_{13}+\beta_{14} \operatorname{LnX} X_{14}+\mathrm{eu}
\end{aligned}
$$

The ability of a model to explain the dependent variable is indicated by the value of the coefficient of determination $\left(\mathrm{R}^{2}\right)$, stating the proportion or percentage of the total variation of independent variables $(\mathrm{X})$ [25]. This value can be estimated using the following formula:

Information :

$$
\mathrm{R}^{2}=(\mathrm{ESS} / \mathrm{TSS})=1-\frac{\Sigma(y i-\hat{\mathrm{y}} i)^{2}}{\Sigma(y i-\bar{y} i)^{2}}
$$

$\mathrm{R}^{2} \quad$ : coefficient of determination

ESS : error sum of square

TSS : total sum of square

yi : respondent's observation i

$\hat{\mathrm{y} i} \quad$ : the forecast of respondent $\mathrm{i}$

yi : average

The adjusted coefficient of determination (adjusted $\mathrm{R}^{2}$ ), on the other hand, is the coefficient of determination that takes degrees of freedom into account (adjusted for). The adjusted $\mathrm{R}^{2}$ has the following mathematical formula::

Information :

$$
\text { Adjust } R^{2}=1-\left(1-R^{2}\right) \frac{(n-k)}{(k-1)}
$$

Adjusted $\mathrm{R}^{2} \quad$ : adjusted coefficient of determination

$\mathrm{k} \quad$ : number of variables excluding intercept

n : number of samples

The F-test and t-test data were used to determine how much the independent factors affected the production. The F-test was a joint variable or model test that looked at the effect of all shallot production variables on the production factor variables at the same time. The F-test is written like this: 
Information :

$$
\begin{aligned}
F_{\text {test }} & =\frac{E S S /(k-1)}{R S S /(n-k)} \\
F_{\text {tabel }} & =\frac{(k-1)}{(n-k)} \cdot \alpha
\end{aligned}
$$

$\mathrm{k} \quad$ : number of variables excluding the intercept

n : number of samples

ESS : explained sum of square

RSS : residual sum of square

$\alpha \quad$ : level of significance

If the analysis result is F-test $>$ : F-table, then the production factors simultaneously affect shallot production. On the other hand, if the analysis result is F-test $<$ : F-table, the production factors have no significant effect on shallot production.

Meanwhile, the influence of production factors on shallot production can be partially estimated by the t-test, formulated as follows:

Information:

$$
t_{t e s t}=\frac{(b i)}{S b i}
$$

bi : coefficient of independent variables

Sbi : standard error of independent variables

If the analysis result of the t-test significance value is less than 0.05 , the production factor partially affects shallot production. Conversely, if the significance value is more than 0.05 , the production factor partially does not affect shallot production.

Maximum profit will be influenced by efficient use of production elements. When the derivative of the profit function on the utilization of production factors is zero, the maximum profit happens mathematically. [23]. It can be stated in the following way:

$$
\Pi=\text { Y.Py }- \text { X.Px }
$$

$\Pi=$ profit

$\mathrm{Y}=$ production or output

Py $=$ output price

$\mathrm{X}=$ input

$\mathrm{Px}=$ input price

Then the derivative of the profit function is:

$$
\begin{aligned}
& d \Pi / d x=d Y / d x \cdot P y-d X / d X . P x \\
& d \Pi / d x=d Y / d x \cdot P y-P x
\end{aligned}
$$

If $\mathrm{dY} / \mathrm{dx}$ Equals marginal production (MP), the marginal production value is $\mathrm{dY} / \mathrm{dx} . \mathrm{Py}(\mathrm{MPV})$. As a result, the most profit happens when:

$$
\begin{aligned}
& \mathrm{d} \Pi / \mathrm{dx}=\mathrm{dY} / \mathrm{dx} . \mathrm{Py}-\mathrm{Px}=0 \\
& \text { or } \\
& \mathrm{dY} / \mathrm{dx} . P y=P x \\
& M P V=P x
\end{aligned}
$$

Such conditions can be said to be in efficient production. Therefore, the efficiency analysis could be seen from the Marginal Production Value (MPV) ratio and the input price $(\mathrm{Px})$. The value of the ratio can be divided into three categories [26]:

MPVxi/Pxi $=1$, means that the use of inputs is efficient and has the potential to achieve maximum profit 
MPVxi/Pxi $>1$, means that the use of production factors is inefficient. Therefore, to achieve an efficient level, the use of these inputs needs to be added.

MPVxi/Pxi $<1$, means that the use of production factors is inefficient. Hence, to achieve an efficient level, the use of these inputs must be reduced.

\section{Results and Discussion}

\subsection{Factors Affecting Shallot Production}

In this study, data on the factors influencing shallot production were taken from 73 farmers. Factors considered affecting shallot production consisted of land area $\left(\mathrm{X}_{1}\right)$, seeds $\left(\mathrm{X}_{2}\right)$, Urea fertilizer $\left(X_{3}\right)$, ZA fertilizer $\left(X_{4}\right)$, TSP fertilizer $\left(X_{5}\right)$, KCL fertilizer $\left(X_{6}\right)$, Pearl NPK fertilizer $\left(\mathrm{X}_{7}\right)$, Saprodap NPK fertilizer $\left(\mathrm{X}_{8}\right), \mathrm{KNO}_{3}$ fertilizer $\left(\mathrm{X}_{9}\right)$, organic fertilizer $\left(\mathrm{X}_{10}\right)$, solid pesticide $\left(\mathrm{X}_{11}\right)$, liquid pesticide $\left(\mathrm{X}_{12}\right)$, family labor $\left(\mathrm{X}_{13}\right)$, and non-family labor $\left(\mathrm{X}_{14}\right)$. The analysis results of the production function of shallots are presented in Table 3.

Table 3 displays that the production function model testing obtained an $\mathrm{R}^{2}$ value (coefficient of determination) of 0.515 . It indicates that the variation in shallot production can be explained by variations in production factors such as land area, seeds, Urea fertilizer, ZA fertilizer, TSP fertilizer, KCL fertilizer, Pearl NPK fertilizer, Saprodap NPK fertilizer, $\mathrm{KNO}_{3}$ fertilizer, organic fertilizer, solid pesticide, liquid pesticide, family labor, and nonfamily labor, by $51.5 \%$. The remaining $48.5 \%$ is explained by other variables excluded in the model.

Table 3. The estimation results of the shallot production function in Pati, Central Java

\begin{tabular}{|l|c|c|c|}
\hline Variable & Coefficient & t-test & Sig \\
\hline Constant & 2.016 & 2.438 & 0.018 \\
\hline Land & 0.327 & 2.485 & $0.016^{* *}$ \\
\hline Seeds & 0.388 & 3.144 & $0.003^{* * *}$ \\
\hline Urea Fertilizer & 0.003 & 0.605 & 0.548 \\
\hline ZA Fertilizer & 0.005 & 0.913 & 0.365 \\
\hline TSP Fertilizer & -0.001 & -0.134 & 0.894 \\
\hline KCL Fertilizer & -0.001 & -0.165 & 0.870 \\
\hline Pearl NPK Fertilizer & 0.081 & 1.532 & 0.131 \\
\hline Saprodap NPK Fertilizer & 0.007 & 0.639 & 0.525 \\
\hline KNO ${ }_{3}$ Fertilizer & 0.021 & 4.282 & $0.000^{* * *}$ \\
\hline Organic Fertilizer & 0.000 & -0.100 & 0.920 \\
\hline Solid Pesticide & -0.013 & -1.477 & 0.145 \\
\hline Liquid Pesticide & -0.005 & -0.942 & 0.350 \\
\hline Family Labor & 0.209 & 2.495 & $0.015^{* *}$ \\
\hline Non-family Labor & 0.125 & 1.159 & 0.251 \\
\hline Adjusted R & 0.515 & & \\
\hline F-test & 6.452 & & \\
\hline F-table $(\alpha=0,01 \%)$ & 2.357 & & \\
\hline N & 73.000 & & \\
\hline t-table & 1.671 & & \\
\hline
\end{tabular}

Information : *** : Significant at $\alpha=1 \%$

$* *$ : Significant at $\alpha=5 \%$

Table 3 demonstrates that the value of the F-test of 6.452 is greater than the F-table of 2.357, then $\mathrm{H}_{0}$ is rejected. It means that independent variables such as land area, seeds, Urea fertilizer, ZA fertilizer, TSP fertilizer, KCL fertilizer, Pearl NPK fertilizer, Saprodap NPK fertilizer, $\mathrm{KNO}_{3}$ fertilizer, organic fertilizer, solid pesticide, liquid pesticide, labor in 
the family, and labor outside the family, simultaneously have a significant effect on shallot production at a confidence level of $99 \%$ or $\alpha=1 \%$. However, based on the t-test analysis, the production factors with a significant effect are land, seeds, and $\mathrm{KNO}_{3}$ fertilizer, while other production factors partially do not significantly affect the production of shallot farming.

At the $95 \%$ confidence level, the variable area of land has a substantial effect on shallot production. The regression coefficient value of the land area variable is 0.327 , meaning that if the land area increases by $1 \%$ and other variables are considered constant, the shallot production will increase by $0.327 \%$. Farmers' land was located in a strategic area. In addition, agricultural land was far from residential areas, so that farmers had the opportunity to increase their land area because they were far from the threat of building construction and physical facilities for non-agricultural businesses.

At the 99 percent confidence level, seeds have a considerable impact on shallot yield. The regression coefficient value of the seed variable is 0.388 , illustrating that if the use of the seed variable is added by $1 \%$, the shallot production will increase by $0.388 \%$. It is because the use of good-quality seeds can increase shallot production.

The $\mathrm{KNO}_{3}$ fertilizer variable has a significant effect on shallot production at the $99 \%$ confidence level. The regression coefficient value of the $\mathrm{KNO}_{3}$ fertilizer variable is 0.021 , implying that if the use of fertilizer is added by $1 \%$, the shallot production will increase by $0.021 \%$.

At the $95 \%$ confidence level, family labor has a considerable impact on shallot production. The value of the family labor regression coefficient of 0.209 indicates that for every additional $1 \%$ of the labor, the production of shallots will increase by $0.209 \%$. This finding is contrary to research on the effect of labor on rice production which states that labor has a negative effect on rice production [27]. Shallots are a type of horticultural crop that requires intensive handling during the cultivation process until harvest and post-harvest so that production and quality are good. This is different from rice commodities which do not need intensive handling during cultivation until harvest.

The analysis results above are similar to the findings of [19], discovering that apart from labor and pesticides, other production factors that affected the production of shallots were land, seeds, and fertilizers. Land and labor provided positive elasticity on various business scales, while seeds provided relatively small positive and negative elasticity on various business scales [22]. In general, the production factors that significantly affected shallot production have positive elasticity. It indicates that land, seeds, $\mathrm{KNO}_{3}$ fertilizer, and labor inputs have the opportunity to be enhanced, thereby potentially increasing income and employment [14].

\subsection{Allocative Efficiency of Shallot Farming}

Price efficiency or allocative is a value showing the relationship between costs and output that can be achieved if maximizing profits by equating the value of the marginal product on each factor of production (input) with each price. The calculation results of allocative efficiency in shallot farming are exhibited in Table 4.

Tabel 4. Allocative Efficiency of Shallot Farming

\begin{tabular}{|l|r|r|r|r|}
\hline \multicolumn{1}{|c|}{ Variable } & Price (Px) & \multicolumn{1}{c|}{ MPV } & \multicolumn{1}{c|}{ K } & Category \\
\hline Land $(\mathrm{m} 2)$ & $1,616.23$ & $4,403.89$ & $2.725^{* * *}$ & Inefficient \\
\hline Seeds $(\mathrm{kg})$ & $19,671.23$ & $417,885.27$ & $21.420^{* * *}$ & Inefficient \\
\hline $\mathrm{KNO}_{3}$ Fert $(\mathrm{kg})$ & $35,000.00$ & $175,230,352.00$ & $5,007.000^{* * *}$ & Inefficient \\
\hline Fam Labor(wd) & $60,000.00$ & $560,694.65$ & $9.340^{* * *}$ & Inefficient \\
\hline
\end{tabular}


The analysis results of allocative efficiency on land use for shallot farming are $2.725>$ 1 , significant at $1 \%$, meaning that land use is inefficient. Hence, it is necessary to increase land area. It is because land use has been maximized so that farmers, when farming activities and production yields are quite high, the profits can cover the costs of land rent.

The increase in the area of planting shallots should be managed efficiently to increase productivity and minimize the conversion of agricultural land [28]. Thus, land expansion efforts can be carried out because the land is still available. Land expansion can be performed by rent or profit-sharing. It is based on the study by [29], discovering that the technical efficiency of farming on owned land is lower than rent or profit-sharing.

The allocative efficiency analysis of the use of the seed production factor has an efficiency value of $21.42>1$, significant at $1 \%$, meaning that the use of the seed fertilizer production factors is inefficient. The price of seeds was relatively high, so the number of seeds purchased by farmers was not in accordance with the area of land being worked on. In addition, too tenuous spacing also affected the use of the seed production factor. To achieve allocative efficiency and higher profits, the seed production factor must be increased. To meet the need for seeds, the role of the government and the private sector is required in facilitating the availability of quality seeds [30]. It was crucial because seed production managed by farmers was generally still characterized as low-quality seeds [31].

The results of the allocative efficiency analysis of the use of the $\mathrm{KNO}_{3}$ fertilizer production factor resulted in an efficiency value of $5,007.00>1$, significant at $1 \%$, implying the inefficient $\mathrm{KNO}_{3}$ fertilizer production factor. Hence, it was necessary to increase its use. In addition, the costs incurred by farmers were very low, and most farmers were unaware of the benefits of $\mathrm{KNO}_{3}$ fertilizer for shallot plants, functioning in the formation of shallot bulbs, thus making them more weighty when harvested. Therefore, it was necessary to treat and apply the fertilizer appropriately to increase efficiency and yields [32].

The analysis of the allocative efficiency of the use of the family labor production factor obtained an efficiency value of $9.340>1$, significant at $1 \%$, indicating its inefficiency. Hence, it was necessary to increase the allocation of its use due to the potential for family labor that has not been appropriately utilized during the shallot farming process.

The findings of this study corroborate other studies showing that land and fertilizer factors have an essential role in crop production. A study of corporate farming models of rice farming in Central Java discovered that land and fertilizers had a significant effect on production, but these factors were not yet efficient in their application [33]. Therefore, the use of production factors still needs to be increased. For the availability of capital to procure production factors, a farming credit policy is required, supported by incentives such as agricultural extension and irrigation facilities to effectively increase agricultural productivity [34].

\section{Conclusions and Recommendations}

The findings of the estimation of the shallot production function revealed that land, seeds, KNO3 fertilizer, and family labor were the production factors that significantly influenced shallot output. In general, the four production factors had a positive effect on shallot production. Thus, the increased use of these production factors would increase shallot production. This condition has been reinforced by the efficiency analysis results, showing that the use of the four production factors was inefficient in shallot farming.

This study implies that to enhance shallot farming, farmers must increase the land area considering the potential of the land is still wide enough to be increased. In addition, farmers also need to increase the use of seeds, $\mathrm{KNO}_{3}$ fertilizer, and labor with relatively cheaper costs. 


\section{References}

1. BPS, Propinsi Jawa Tengah Dalam Angka (Semarang, 2019).

2. BPS, Kabuapten Pati Dalam Angka (Pati, 2019).

3. M. Z. Rijib and O. K. Jbara, Measuring the technical efficiency and the rate of change in the tfp for farms rain-fed wheat in the region in light of differing size area. Iraqi $\mathrm{J}$. Agric. Sci. 47, 1475 (2016).

4. F. M. Mirza, N. Najam, M. Mehdi, and B. Ahmad, Determinants of technical efficiency of wheat farms in Pakistan. Pakistan J. Agric. Sci. 52, 577 (2015).

5. A. A. Chandio, Y. Jiang, A. T. Gessesse, and R. Dunya, The Nexus of Agricultural Credit, Farm Size and Technical Efficiency in Sindh, Pakistan: A Stochastic Production Frontier Approach. J. Saudi Soc. Agric. Sci. 18, 348 (2019).

6. N. Panpluem, A. Mustafa, X. Huang, S. Wang, and C. Yin. Measuring the Technical Efficiency of Certified Organic Rice Producing Farms in Yasothon Province: Northeast Thailand. Sustain. 11, (2019).

7. J. H. Seok, H. Moon, G. S. Kim, and M. R. Reed. Is aging the important factor for sustainable agricultural development in Korea? Evidence from the relationship between aging and farm technical efficiency. Sustain. 10, (2018).

8. C. A. Arellano and J. A. D. Reyes. Effects of farmer-entrepreneurial competencies on the level of production and technical efficiency of rice farms in Laguna, Philippines. J. Int. Soc. Southeast Asian Agric. Sci. 25, 45 (2019).

9. A. Ebers, T. T. Nguyen, and U. Grote. Production efficiency of rice farms in Thailand and Cambodia: a comparative analysis of Ubon Ratchathani and Stung Treng provinces. Paddy Water Environ. 15, 79 (2017).

10. M. H. Ahmed and K. A. Melesse. Impact of off-farm activities on technical efficiency: Evidence from maize producers of eastern Ethiopia. Agric. Food Econ. 6, 1 (2018).

11. A. Sekara, R. Pokluda, L. Del Vacchio, S. Somma, and G. Caruso. Interactions among genotype, environment and agronomic practices on production and quality of storage onion (Allium cepa L.) - A review. Hortic. Sci. 44, 21 (2017).

12. H. F. Abouziena and S. M. Radwan. Allelopathic effects of sawdust, rice straw, burclover weed and cogongrass on weed control and development of onion. Int. J. ChemTech Res. 7, 337 (2015).

13. G. Pellejero, A. Miglierina, G. Aschkar, M. Turcato, and R. Jiménez-Ballesta. Effects of the onion residue compost as an organic fertilizer in a vegetable culture in the Lower Valley of the Rio Negro. Int. J. Recycl. Org. Waste Agric. 6, 159 (2017).

14. S. Laxmi, C. Sen, and R. Singh. Profitability, potential and progress of organic onion production: Evidences from Nalanda district of Bihar. Econ. Aff. 62, 33 (2017).

15. R. Babilie, M. Jbour, and B. A. Trabi. Effect of foliar spraying with licorice root and seaweed extractson growth and seed production of onion (Allium cepa L.). Int. J. ChemTech Res. 8, 557 (2015).

16. M. M. A. Hussein, K. A. M. Abo-Elyousr, M. A. H. Hassan, M. Hashem, E. A. Hassan, and S. A. M. Alamri. Induction of defense mechanisms involved in disease resistance of onion blight disease caused by Botrytis allii. Egypt. J. Biol. Pest Control 28, (2018).

17. L. S. M. Geries, T. A. El-Shahawy, and E. A. Moursi. Cut-off irrigation as an effective tool to increase water-use efficiency, enhance productivity, quality and storability of some onion cultivars. Agric. Water Manag. 244, (2021).

18. S. Panneerselvam, A. Rakesh, R. Saravana Kumar, S. Saravanan, and R. O. Yadunath 
Gurudeep. Design and fabrication of automatic onion planting machine. Int. J. Innov. Technol. Explor. Eng. 8, 373 (2019).

19. M. A. Wahib. Eficiency of Production Factor of Red Onion Farming in Indonesia. RJOAS 5, 255 (2017).

20. M. Haque, M. M. Miah, S. Hossain, M. Rahman, and M. Moniruzzaman. Profitability Of Onion Cultivation In Some Selected Areas Of Bangladesh. Bangladesh J. Agric. Res. 36, 427 (1970).

21. M. Baree. Measuring Technical Efficiency of Onion (Allium cepa L.) Farms in Bangladesh. Bangladesh J. Agric. Res. 37, 171 (2012).

22. D. D. E. Sellos, D. E. L. Asfáltica, E. M. El, C. D. E. Washoe, L. G. Loría, E. Hajj, P. Sebaaly, and A. Navas. a Comparative Study of Technical Efficiency of Onion Producing Farms in Bangladesh. Progress. Agric. 22, 1 (2011).

23. D. L. Debertin, Agricultural Production Economics, Second edi (Macmillan Publishing Company, 2012).

24. Soekartawi, Agribisnis : Teori Dan Aplikasinya (PT Raja Grafindo, Jakarta, 2007).

25. Gujarati, Dasar-Dasar Ekonometrika (Erlangga, Jakarta, 2006).

26. Soekartawi, Teori Ekonomi Produksi, Dengan Pokok Bahasan Analisis Fungsi CobbDouglas (Grafindo, Jakarta, 1993).

27. Triyono, N. Rahmawati, and B. H. Isnawan. Technical efficiency of rice farm under risk of uncertainty weather in Yogyakarta, Indonesia IOP Conf. Ser. Earth Environ. Sci. 423, (2020).

28. I. Y. Prasada and M. Masyhuri. The Conversion of Agricultural Land in Urban Areas (Case Study of Pekalongan City, Central Java). Agrar. J. Agribus. Rural Dev. Res. 5, (2019).

29. D. Defidelwina, J. Jamhari, L. R. Waluyati, and S. W. Widodo. Dampak Kepemilikan Lahan Padi Sawah Terhadap Efisiensi Teknis dan Efisiensi Lingkungan di Kabupaten Rokan Hulu. Agrar. J. Agribus. Rural Dev. Res. 5, (2019).

30. A. Sembiring, R. R. Murtiningsih, and K. Kusmana. G0 Potato Seed Production Management in Indonesia: An Overview and The Challenges. Agrar. J. Agribus. Rural Dev. Res. 7, 78 (2021).

31. W. Adiyoga. Seed Systems in the Four Shallot Producing Areas of Java: A Focus Group Discussion. E3S Web Conf. 232, (2021).

32. T. K. Sari, M. Rif'an, and S. Sakhidin. Effects of NP-SR Fertilizer Composition and Water Logging on Soil Chemical Properties and N Fertilizer Efficiency in Paddy Field. PLANTA Trop. J. Agrosains (Journal Agro Sci. 9, 10 (2021).

33. M. J. Iskandar and J. Jamhari. Efficiency of Rice Farming in the Corporate Farming Model in Central Java Agrar. J. Agribus. Rural Dev. Res. 6, 154 (2020).

34. G. Wirakusuma and I. Irham. Can Credit Program Improve Agricultural Productivity? Evidence from Indonesia. E3S Web Conf. 232, 1 (2021). 